\title{
PEMBELAJARAN ADVOKASI: ALTERNATIF SOLUSI MENINGKATKAN HASIL BELAJAR SISWA DI ABAD 21
}

\author{
'Aabidah Ummu 'Aziizah ${ }^{1}$, Nisa Bella ${ }^{1}$, Ibrahim ${ }^{1}$ \\ ${ }^{1}$ Universitas Islam Negeri Sunan Kalijaga, Yogyakarta \\ *Corresponding email: aabidah319@gmail.com
}

Naskah diterima: 24 Juli 2021| Disetujui: 20 Agustus2021 | Diterbitkan: 22 Agustus 2021

\begin{abstract}
This study aims to determine the extent of the development of the implementation of advocacy learning and develop it as an alternative solution in improving student learning outcomes in the 21 st century. This research method uses qualitative research with a library research approach and is descriptive in nature and applies the Systematic Literature Review (SLR) method. Data collection is done by looking at previous research empirically whether it is qualitative, quantitative or mixed methods. Meanwhile, the analysis and evaluation of the data was carried out using a data table containing the classification of previous researches focused on each discussion of the keywords in this study. The results of this study indicate that (1) research on advocacy learning models still revolves around a micro scope which is limited in its application to debate activities and subject matters that are open-ended and only focused on the student's point of view, (2) The development of advocacy learning models can be done through macro actualization of advocacy models on various learning methods and not only limited to exact or non-exact topics, open-ended or closed-ended and advocacy model reviews can be intended for two points of view, namely teachers and students.
\end{abstract}

Keywords: Learning, Advocacy, Learning Outcomes

\begin{abstract}
Abstrak: Penelitian ini bertujuan untuk mengetahui sejauh mana perkembangan penerapan pembelajaran advokasi dan mengembangkannya sebagai solusi alternatif dalam meningkatkan hasil belajar siswa di abad 21. Metode penelitian ini menggunakan penelitian kualitatif dengan pendekatan studi kepustakaan (library research) dan bersifat deskriptif serta menerapkan metode Systematic Literature Review (SLR). Pengumpulan data dilakukan dengan melihat secara empiris penelitian terdahulu baik yang sifatnya kualitatif, kuantitatif, ataupun mix method. Sedangkan analisis dan evaluasi data dilakukan dengan tabel data berisikan klasifikasi riset-riset terdahulu yang difokuskan pada tiap pembahasan kata kunci dalam penelitian. Hasil dari penelitian ini menunjukkan bahwa (1) penelitian model pembelajaran advokasi masih berputar pada lingkup mikro yang terbatas penerapannya pada aktivitas perdebatan dan persoalan mata pelajaran yang sifatnya open-ended serta hanya terfokus pada sudut pandang siswa, (2) pengembangan model pembelajaran advokasi dapat dilakukan melalui aktualisasi model advokasi secara makro pada ragam metode pembelajaran dan tidak hanya dibatasi pada topik-topik eksak ataupun non eksak, open-ended ataupun close-ended dan tinjauan model advokasi dapat diperuntukkan bagi dua sudut pandang yakni guru dan murid.
\end{abstract}

Kata kunci: Pembelajaran, Advokasi, Hasil Belajar 


\section{PENDAHULUAN}

Diskusi terkait dengan pendidikan merupakan sebuah bahasan yang selalu bergulir dan tidak pernah habis. Bahkan dikatakan bahwa pendidikan adalah suatu masalah yang tidak pernah selesai (Tafsir, 2019). Term pendidikan sering dipahami sebagai usaha untuk menumbuhkembangkan potensi bawaan manusia berupa jasmani dan rohani. Dengannya kemudian memposisikan urgensi pendidikan bagi kehidupan manusia menjadi unggul dibandingkan kebutuhan yang lain. Dibutuhkan banyak perangkat dalam mewujudkan suatu pendidikan (Tabroni, 2013), tidak hanya materi pembelajaran yang matang, pendidik yang kompeten dan ketersediaan sarana prasarana, namun juga hal-hal metodik seperti model pembelajaran (Abdurrahmansyah \& Abdulhak, 2012).

Esensi pendidikan dapat dikatakan terletak pada proses pembelajaran yang dilakukan, di mana di dalamnya terjadi proses transmisi pengetahuan dari pendidik kepada peserta didik (Hamalik, 1991). Di mana internalisasi spirit pendidikan akan berlangsung selama proses tersebut, sehingga bagaimana kemudian suatu proses pembelajaran digunakan melalui beberapa macam model pengajaran akan menentukan kualitas output peserta didik nantinya (Ibrahim \& Widodo, 2020). Tidak hanya itu, pendidikan juga merupakan garda pertama dalam menjawab laju zaman di abad 21 ini yang seluruhnya dituntut untuk memiliki ketrampilan berpikir tingkat tinggi dan mengakibatkan pergeseran orientasi pendidikan lain di peradaban terkini (Ibrahim, 2020). Abad 21 dapat dikatakan sebagai abad pengetahuan, sebuah abad di mana terjadi proses transformasi besar-besaran yang memberikan pengaruh besar bagi pendidikan. Dibutuhkan perubahan yang bukan terkait dengan kurikulum dan mengarah pada pedagogis, yaitu perubahan dari simple action menuju pada comprehensive action. Sehingga siswa nantinya akan didorong agar memiliki basis pengetahuan dan pemahaman yang mendalam untuk menjadi pembelajar abadi (lofe-long learner) (Afandi et al., 2016).

Percepatan perkembangan arus global tidak lagi hanya berkutat pada retorika pengetahuan yang disajikan oleh seorang guru di dalam kelas (Hirschman \& Wood, 2018), melainkan sebagai siswa juga belajar bagaimana cara belajar dengan menyampaikan secara bebas pengalaman yang dimilikinya dengan asumsi akan mendapatkan respon positif dari pengetahuan yang tengah dipelajari (Syahputra, 2018). Persiapan seorang siswa untuk menghargai pengalaman hidupnya dan menuangkannya dalam diskusi-diskusi kelas akan membangun motivasi belajar yang tinggi dalam kepribadiannya.

National Education Association telah merumuskan karakteristik pembelajaran abad 21 yang mengandung empat ragam keterampilan atau yang dikenal dengan "The 4Cs"(Chiruguru, 2020), meliputi berpikir kritis, kreativitas, komunikasi, dan kolaborasi. Keterampilan berpikir kritis adalah kemampuan untuk melakukan analisis, penilaian, evaluasi, rekonstruksi, dan pegambilan keputusan 
yang mengarah pada tindakan rasional dan logis (Arif, 2019). Sedangkan berpikir kreatif adalah tentang menemukan hal-hal baru yang belum dijumpai sebelumnya dan kemudian mengembangkannya sebagai solusi dari beragam masalah (Redhana, 2019). Keterampilan berkomunikasi berfokus pada kemampuan seseorang untuk mengungkapkan pemikiran, gagasan, pengetahuan atau sekadar informasi baru yang dimilikinya baik secara tertulis maupun lisan (Marfuah., 2017). Keterampilan berkolaborasi atau yang lebih dikenal dengan ketrampilan bekerja sama secara efektif dengan tetap menunjukkan rasa hormat kepada sesama anggota kelompok yang memiliki latar belakang beragam guna membentuk suatu keputusan bersama (Sunbanu et al., 2019)

Pengembangan pendidikan melalui pembelajaran advokasi merupakan salah satu alternatif yang ditawarkan dalam mewujudkan tujuan-tujuan pembelajaran di abad 21. Peserta didik diberikan kesempatan untuk mempelajari dan mengetengahkan isu-isu sosial dan untuk selanjutnya dapat mengajukan pendapat yang bertalian dengan topik tersebut dengan sudut pandang yang beragam (Nurwahidah \& Muttaqin, 2018). Demokrasi menjadi asas utama dalam pendekatan advokasi guna mewujudkan iklim pembelajaran yang sehat dan mencerdaskan, peserta didik dituntut untuk berpikir dengan bebas dan bertindak dengan penuh tanggung jawab (Lisnawati, 2020).

Seluruh model pembelajaran sejatinya selalu bermuara pada tujuan utama yakni guna mengarahkan dan mengembangkan perubahan pada diri siswa secara terencana baik dari segi kognitif, afektif, dan psikomotorik (Romdloni, 2018). Namun pembelajaran advokasi diklaim memiliki dimensi pembelajaran yang meluas dibandingkan model pembelajaran lain. Kompetensi sikap dan kognitif siswa tidak hanya berkutat pada materi pembelajaran namun juga wawasan di sekitar kehidupan siswa secara lebih aktual seperti isu-isu sosial atau semacamnya (Haryanto \& Suhartono, 2019).

Pembelajaran advokasi dalam kaitannya dengan peningkatan hasil belajar pada siswa, biasanya terfokus pada variabel menyusun topik, menyusun argumen, menyusun sanggahan, peraturan perdebatan, dan perdebatan itu sendiri (Dananjaya, 2010). Apabila indikator tersebut terlaksana dalam proses pembelajaran maka secara otomatis akan menimbulkan rangsangan yang sifatnya positif untuk memotivasi belajar para siswa (Hamid, 2019). Sebagaimana hasil penelitian sebelumnya yang membuktikan signifikansi hubungan antara motivasi belajar dengan hasil belajar siswa secara positif (Yanuarti \& Rosmayanti, 2019).

Kegiatan advokasi yang berisikan penyusunan topik untuk selanjutnya membangun argumen dan sanggahan yang kemudian diuji dalam aktivitas perdebatan edukatif serta komunikatif dengan cara mengadu argumen antara siswa merupakan proses pembelajaran yang menyenangkan (Nurwahidah \& Muttaqin, 2018). Masing-masing adrenalin siswa berpacu untuk beradu satu sama 
lain menemukan pendapat yang mayoritas. Rasa semangat tersebut jika mengacu sebagaimana dikatakan Sardiman yang dikutip (Oktiani, 2017) mutlak dihasilkan oleh motivasi belajar siswa sebagai keseluruhan daya penggerak diri dalam berkegiatan belajar. Selain itu, motivasi belajar juga merupakan energi, penjamin kelangsungan dan pemberi arah kegiatan belajar hingga akhirnya tercapai (Afryansih, 2017)

Dalam penelitian terdahulu pembelajaran model advokasi banyak digunakan pada mata pelajaran yang bersifat non-scientist seperti pendidikan agama islam, fikih dan lain-lain (Mustolih, 2020). Baru beberapa tahun terakhir bermunculan pembelajaran advokasi pada mata pelajaran yang bersifat eksak seperti disiplin ilmu matematika (Ibrahim \& Widodo, 2020). Menjadi sulit untuk dibayangkan apabila kegiatan perdebatan siswa diterapkan pada mata pelajaran yang sifatnya undebatable (tidak layak untuk diperdebatkan), hal ini tidak hanya ditemui di bidang-bidang eksak, sebagai contoh materi akidah, bagaimana kemudian para siswa memperdebatkan hal yang sudah mutlak keberadaannya dengan bangunan-bangunan argumen yang ada.

Oleh karenanya dalam keberlangsungan proses pembelajaran di dunia pendidikan ini sangat dibutuhkan penelitian mendalam terkait literature review model pembelajaran advokasi dalam mengupayakan hasil belajar siswa di abad 21. Jika nantinya ditemukan kelebihan dalam pembelajaran advokasi, maka dapat dikembangkan untuk ke depannya. Brgitupun sebaliknya jika ternyata terdapat kelemahan-kelemahan proses model advokasi, untuk selanjutnya dapat mencari solusi alternatif yang solutif. Penulis akan berfokus pada penelitian-penelitian terdahulu yang berkaitan dengan model pembelajaran advokasi dalam meningkatkan hasil belajar siswa di berbagai mata pelajaran.

\section{METODE}

Penelitian ini menggunakan metode penelitian kualitatif dengan pendekatan studi kepustakaan (library research) dan bersifat deskriptif atau yang lebih dikenal dengan literature review. Sehingga pada penelitian ini juga menerapkan metode Systematic Literature Review (SLR), istilah tersebut digunakan untuk merujuk pada metodologi penelitian tertentu dan pengembangan yang dilakukan untuk mengumpulkan serta mengevaluasi penelitian sebelumnya yang terkait pada topik tertentu (Triandini et al., 2019). Peneliti memilih metode SLR guna mengidentifikasi, mengkaji, mengevaluasi, dan menafsirkan semua penelitian yang tersedia dengan topik yang terkait (Barricelli et al., 2019). Prosedur SLR sebagaimana yang dirumuskan (Cooper, 1988) dimulai dari (1) merumuskan masalah, (2) mengumpulkann data, (3) mengevaluasi kelayakan data, (4) menganalisis dan menginterpretasi data yang relevan, dan (5) mengatur dan menyajikan hasil dan selanjutnya dibandingkan satu sama lain dengan isu-isu terkini. 


\section{Pengumpulan Data}

Dilakukan pengumpulan data guna menemukan studi empiris yang meliputi riset kulitatif, kuantitatif, metode campuran dan bahkan ulasan literatur lain dalam jurnal, skripsi ataupun tesis sejak tahun 2015 guna mengungkap lingkup penelitian pembelajaran advokasi di lembaga pendidikan formal. Kata kunci yang digunakan adalah "pembelajaran di abad 21/ Learning in $21^{\text {st }}$ Century", "pembelajaran advokasi/advocation learning", "pendekatan advokasi/advocation approach", "peningkatan hasil belajar/improvement of learning outcomes". Database atau dataset yang digunkaan untuk penelitian literatur adalah Google Scholar, Research Gate, Directory of Open Access Journal (DOAJ) dan Academia.Edu.

\section{Analisis dan Evaluasi Data}

Berdasarkan prosedur di atas, ditemukan 48 riset. Dari jumlah tersebut, 28 difokuskan pada isuisu yang berkaitan dengan pembelajaran advokasi, 10 difokuskan pada upaya peningkatan hasil belajar siswa dan 10 sisanya difokuskan pada pengembangan pembelajaran advokasi dalam menjawab tantangan peningkatan hasil belajar siswa di abad 21. Artikel yang tersisa dikeluarkan dari tinjauan ini karena tidak berkaitan langsung dengan dua rumusan masalah utama penelitian. Selanjutnya, peneliti membatasi pencarian literatur dengan kata kunci dan database yang telah ditentukan sebelumnya. Berikut rincian tabel 1 penjelasan dari pernyataan di atas.

Table 1. Fokus dan Sumber

\begin{tabular}{|c|c|c|}
\hline No & Fokus & Sumber \\
\hline 1. & Pembelajaran di Abad 21 & $\begin{array}{l}\text { Ibrahim (2020); Afandi, A., Junanto, T., \& Afriani, R. (2016); } \\
\text { Hirschman \& Wood (2018); Syahputra (2018); ET (t.t); Chiruguru } \\
\text { (2020); Arif (2019); Redhana (2019); Marfuah (2017); Sunbanu, Felda } \\
\text { H., Mawardi \& Wardani K. W., (2019). }\end{array}$ \\
\hline 2. & $\begin{array}{l}\text { Metode } \\
\text { Advokasi }\end{array}$ & $\begin{array}{l}\text { Abdurrahmansyah, A., \& Abdulhak, I. (2012); Afandi, A., Junanto, T., } \\
\text { \& Afriani, R. (2016); Afryansih, N. (2017); Alexander, F., Manuain, } \\
\text { L. M. M., Silla, W. Y., \& Dami, Z. A. (2020); Dananjaya, U. (2010); } \\
\text { Fox, I., \& Wiens, J. (2019); Hamalik, O. (1991); Hamalik, O. (2008); } \\
\text { Hamid, E. A. (2019); Haryanto, H., \& Suhartono, S. (2019); Ibrahim. } \\
\text { (2020); Ibrahim, \& Widodo, S. A. (2020); Lilik, W. (2021); Lisnawati, } \\
\text { L. (2020); Mukharrom, M. T. (2004); Mustolih, M. (2020); } \\
\text { Nurwahidah, N., \& Muttaqin, Z. (2018); Oktiani, I. (2017); Romdloni, } \\
\text { R. (2018); Silberman, M. L. (2020); Sinaga, S. E. (2013); Suharto, E. } \\
\text { (2007); Tabroni, T. (2013); Tafsir, A. (2019); Yanuarti, H., \& } \\
\text { Rosmayanti, D. (2019); Zulyadi, T. (2014). }\end{array}$ \\
\hline
\end{tabular}




\begin{tabular}{|c|c|c|}
\hline 3. & $\begin{array}{l}\text { Upaya Peningkatan Hasil } \\
\text { Belajar Siswa }\end{array}$ & $\begin{array}{l}\text { Anggrayni, Y. (2011); Bradley-Levine, J. (2018); irmannisa, D., \& } \\
\text { Imaniyati, N. (n.d.); Ifa, M. (2013); Palittin, I. D., Wolo, W., \& } \\
\text { Purwanty, R. (2019); RAHMAWATI, R. (n.d.); Setiawan, I., \& } \\
\text { Nyoman, G. A. (2008); Sjukur, S. B. (2012); Suminah, S., Gunawan, } \\
\text { I., \& Murdiyah, S. (2018); Ulfah, K. R., Santoso, A., \& Utaya, S. } \\
\text { (2016) }\end{array}$ \\
\hline 4. & Pengembangan & Athanases, S. Z., \& Martin, K. J. (2006); Bradley-Levine, J. (2018); \\
\hline & $\begin{array}{l}\text { Pembelajaran } \\
\text { untuk }\end{array}$ & $\begin{array}{l}\text { Hidayani, S. (2016); Hilmawan, T. (2020); Ibrahim, Sujadi, I., Maarif, } \\
\text { S., \& Widodo, S. A. (2021); Iswari, A. P. (2017); Septiani, U., \& }\end{array}$ \\
\hline & $\begin{array}{l}\text { Peningkatan Hasil Belajar } \\
\text { Siswa di Abad } 21\end{array}$ & $\begin{array}{l}\text { Zanthy, L. S. (2019); Tandililing, E. (2013); Waterston, T. (2009); } \\
\text { Woldt, A. L. (2009) }\end{array}$ \\
\hline
\end{tabular}

\section{HASIL DAN PEMBAHASAN}

\section{Pembelajaran Advokasi}

Term advokasi pertama kali diperkenalkan melalui ruang lingkup hukum. Advokasi digunakan untuk menyebut pembela atau pengacara yang melakukan suatu kegiatan berupa membela kasus atau perkara di pengadilan, bahkan advokasi tidak hanya berkaitan dengan pembelaan melainkan juga mengemukakan sesuatu bahkan melakukan perubahan (Suharto, 2007). Adanya advokasi merupakan suatu upaya sosial untuk terjadi suatu perubahan ke arah positif, biasanya dari masyarakat kepada pemerintah agar kemudian tercipta sebuah keadilan sosial dalam berkehidupan (Zulyadi, 2014). Tidak jarang advokasi menaruh perhatian pada hal-hal yang sifatnya terselubung di balik suatu kebijakan atau fenomena, sehingga dapat dikatakan kegiatan advokasi adalah kegiatan mengkritisi fenomena (Mukharrom, 2004).

Pendidikan mengadopsi term advokasi dengan konsep yang tidak jauh berbeda. Suatu model pembelajaran yang berbasis pada critical thinking (Ibrahim, Sujadi, Maarif, \& Widodo, 2021) dengan perwujudan aktivitas pembelajaran yang beragam, terkadang dengan membentuk kelompok debat (Fox \& Wiens, 2019), komunikasi interaktif antara guru dan murid dengan didahului pembekalan berupa penyampaian materi ataupun keteladanan secara langsung (Nurwahidah \& Muttaqin, 2018). Sehingga pada hakikatnya model pembelajaran advokasi ialah pembelajaran yang memusatkan pada siswa (student centered) yang kemudian oleh sebagian praktisi diidentikkan dengan aktivitas debat padahal tidak hanya itu karena intinya para siswa dituntut untuk berani berbicara menyampaikan pendapatnya dengan argumentasi yang dimiliki dan bertanggung jawab akan hal itu (Lilik, 2021).

Menurut (Hamalik, 2008) yang menetapkan beberapa prinsip pembelajaran advokasi yang tidak dimiliki oleh model pembelajaran lain, di antaranya (1) sifat ke-aku-an yang mendominasi disaat 
siswa menyampaikan pendapat, (2) motivasi belajar yang tinggi akibat proses debat yang memicu semangat siswa, (3) para siswa terbiasa fokus pada topik-topik penting pembahasan baik yang sifatnya personal ataupun sosial, (4) banyak pembelajaran yang dikandung dalam setiap topik pembahasan, karena model advokasi mengharuskan siswa mengulik lebih dalam isu-isu yang sedang diketengahkan, (5) model advokasi memperkuat penyimpanan (retention) terhadap prinsip-prinsip argumentasi yang efektif, (6) model pembelajaran advokasi dapat diterapkan di seluruh jenjang pendidikan dengan konsep yang menyesuaikan usia perkembangan peserta didik, (7) mengembangkan ketrampilan dalam berlogika, (8) berpikir kritis, (9) melatih kemampuan verbal, (10) mengembangkan aspek afektif seperti konsep diri, (11) melatih kemandirian, dan (12) meningkatkan rasa percaya diri.

Proses pembelajaran advokasi biasanya dimulai dengan mendudukkan para peserta didik dengan format dua kubu yang saling berhadapan. Masing-masing keduanya diharuskan untuk mengenali topik pembahasan dan selanjutnya membangun argumentasi untuk nantinya dikemukakan (Silberman, 2020). Format lain dikemukakan (Alexander, 2020) melalui penentuan topik bahasan, lalu pembagian siswa menjadi lebih dari dua kubu, kemudian masing-masing kubu diperintahkan untuk mempresentasikan hasil argumentasinya dalam menanggapi isu yang tengah beredar. Ketika salah satu kelompok memperesentasikan hasil temuannya maka kelompok lain ditugasi pengajar sebagai tim oposisi yang wajib bertanya kepada kelompok presentator. Hal terpenting menurut Alexander adalah adanya dialog interaktif antar sesama manusia, maka itulah yang dinamakan sebagai proses belajar mengajar model advokasi.

Penerapan advokasi di ruang belajar dengan menitikberatkan pada pengangkatan isu sosial di sekeliling siswa menjadikannya banyak digunakan dalam mata pelajaran sosial yang cenderung konkret dan non eksakta seperti pendidikan kewarganegaraan, fikih dan mata pelajaran keagamaan lain. Hal ini dirasa wajar karena tema pembelajaran yang dapat diterapkan pada model pembelajaran advokasi secara mikro hanyalah tema yang memiliki kebenaran multi perspektif dan isu-isu sosial adalah suatu topik di tengah masyarakat yang dapat ditinjau dengan beragam dimensi pendekatan. Sebagai contoh membahas "Pemaknaan Ketuhanan Yang Maha Esa" pada mata pelajaran PKN, apakah kalimat tersebut bermakna hanya ada satu agama yang sah di Indonesia atau justru menggambarkan kemajemukan dalam beragama di Indonesia.

Beberapa tahun terakhir, pembelajaran advokasi mencoba dibawa kepada pembelajaran yang sifatnya eksakta seperti mata pelajaran matematika. Penelitian Sinaga (2013) yang mengangkat Perbedaan Kemampuan Berpikir Kritis dan Kreatif Siswa SMP dalam Matematika dengan Pembelajaran Konvensional Melalui Pendekatan Advokasi dengan Penyajian Masalah Open-Ended, 
lalu penelitian Ibrahim yang mengangkat pembelajaran advokasi untuk menyelesaikan permasalahan open-ended pada mata pelajaran matematika (Ibrahim \& Widodo, 2020) dan pendekatan advokasi guna meningkatkan daya pikir kritis pada mata pelajaran matematika (Ibrahim et al., 2021) telah menunjukkan secara ilmiah bahwa model pembelajaran advokasi sangat fleksibel untuk dibawa kepada tema-tema eksak.

Perbandingan dari penerapan pembelajaran advokasi di masa lalu dan masa kini hanya terletak pada materi pembelajaran yang beralih dari tema-tema non eksak menjadi eksak, namun terkait pengembangan metodologi pada materi yang berbeda tidak ditemukan. Sebagai contoh penerapan advokasi pada mata pelajaran fikih yang bertujuan untuk meningkatkan pemahaman siswa terhadap dalil-dalil keagamaan dan keragaman tata peribadatan yang ditemukan pada lingkup masyarakat (Hamid, 2019). Pada mata jenjang pendidikan SMP, terdapat haji dan umrah, di dalamnya memuat rukun haji dan umrah beserta permasalahan-permasalahan terkait seperti vaksin meningitis haji dan umrah yang menurut beberapa kabar mengandung babi (HIMPUNAN FATWA MAJELIS ULAMA INDONESIA, n.d.). Para siswa diminta untuk menyampaikan pendapatnya mengenai beberapa permasalahan terkait haji dan umrah dengan dasar-dasar pembelajaran yang sebelumnya telah dibahas. Diharapkan siswa akan menyampaikan pendapat yang saling bertolak belakang, mengingat pembahasan-pembahasan fikih sifatnya ijtihadi dan mazhabi sehingga sangat mungkin untuk memiliki pendapat yang berbeda dengan sebab dasar dalil yang berbeda namun dibenarkan secara fikih.

Sementara penerapan pembelajaran advokasi pada ranah eksak seperti mata pelajaran matematika hanya diberikan pada materi-materi yang bersifat open ended. Sifat open ended tersebut dapat diklasifikasikan pada tiga tipe, yakni keterbukaan dalam proses, keterbukaan dalam hasil, dan keterbukaan dalam metodologis (Dahlan, 2004). Oleh sebab itu tidak semua materi matematika dapat menerapkan pembelajaran advokasi. Materi penjumlahan sederhana antara 9 dan 8 memiliki beragam cara untuk menemukan hasil 17, dalam hal ini siswa diberikan kesempatan untuk menyampaikan opini pribadinya, apakah menggunakan cara manual atau menggunakan cara simpan angka dalam pikiran dan menyisakan angka lain pada jari tangan atau cara lainnya yang pada dasarnya seluruh cara tersebut benar dan menghasilkan angka yang sama.

\section{Upaya Peningkatan Hasil Belajar Siswa}

Meningkatkan hasil belajar siswa bermakna meningkatkan tingkat pengetahuan yang dicapai siswa terhadap materi yang diterima ketika mengikuti dan mengerjakan tugas dan kegiatan pembelajaran (Ifa, 2013). Hasil belajar siswa tidak hanya diidentikkan dengan nilai kognitif namun juga perubahan tingkah laku secara umum baik pengetahuan, pemahaman, sikap, dan keterampilan 
peserta didik sehingga menjadi lebih baik dari sebelumnya (Sjukur, 2012), atau dengan kata lain hasil belajar siswa dapat berupa aspek kognitif, psikomoto, maupun afektif (Setiawan \& Nyoman, 2008). Aspek kognitif meliputi penguasaan konsep dan prinsip serta kinerja pemecahan masalah. Sedangkan aspek psikomotor ditunjukkan melalui keterampilan fisik dalam melakukan eksperimen (pengamatan). Lain halnya dengan aspek afektif yang ditunjukkan melalui sikap siswa terhadap pelajaran dan pembelajaran. Ketiga aspek tersebut dapat menjadi alat ukur hasil belajar yang valid selama peningkatan kognitif, psikomotorik, dan afektif siswa dihasilkan dari pembelajaran yang dilakukan (Suminah et al., 2018).

Peningkatan hasil belajar siswa ditentukan oleh berbagai faktor internal dan eksternal. Di antara yang paling dominan ialah fasilitas belajar yang dimiliki oleh siswa. Fasilitas belajar tidak hanya terkait benda-benda yang diperlukan dalam proses belajar mengajar sebagaimana penuturan Muhroji yang dikutip Firmannisa, yakni semua hal yang diperlukan dalam proses belajar mengajar baik bergerak maupun tidak bergerak guna mencapai tujuan pendidikan yang efektif, lancar, dan efisien serta model pembelajaran termasuk dalam hal itu. Sehingga pemilihan model pembelajaran yang tepat adalah salah satu faktor penentu akan keberhasilan suatu pembelajaran. Anggrayni (Anggrayni, 2011) dalam penelitiannya mendapati bahwa persentase terbesar yang mempengaruhi kemunculan motivasi pada siswa adalah faktor fisiologi, sosial, psikologi, non-sosial dan pendekatan belajar. Faktor pendekatan belajar di antaranya meliputi model pengajaran yang diterapkan oleh guru di kelas.

Sementara itu salah satu karakteristik dari pembelajaran advokasi mengklaim dirinya mampu untuk menumbuhkan motivasi yang tinggi pada diri siswa sehingga belajar tidak hanya berisikan pentransmisian keilmuan atau hanya penuntasan formalitas kurikulum pendidikan namun juga mampu untuk mewujudkan rasa suka cita sekaligus minat yang tinggi dalam belajar (Bradley-Levine, 2018). Seperti halnya hasil penelitian-penelitian terdahulu telah membuktikan bahwa motivasi yang tinggi berpengaruh secara signifikan pada hasil belajar siswa, sebagai contoh penelitian Ulfah dkk tentang Hubungan Motivasi dengan Hasil Belajar IPS yang menyatakan bahwa motivasi yang tinggi menjadi faktor penentu dari tingginya hasil belajar (Ulfah et al., 2016). Penelitian Palittin dkk terkait Hubungan Motivasi Belajar dengan Hasil Belajar Siswa yang menyatakan bahwa secara signifikan motivasi belajar memiliki hubungan berbanding lurus dengan hasil belajar siswa (Palittin et al., 2019).

Aspek motivasi merupakan karakteristik utama yang dimiliki pembelajaran advokasi dan sekaligus daya penggerak dari pembelajaran. Aktivitas pembelajaran advokasi tergolong sebagai pembelajaran intruksional yang melakukan pembelajaran dengan penuh perencanaan yang berisikan tahapan pre learning, during learning, dan post learning (Darmawan, 2006). Tiga tahapan tersebut selalu berupaya untuk menumbuhkan dan mempertahankan motivasi siswa dalam menimba ilmu 
dengan cara pengawasan intelektual guru selama proses berlangsung. Dengan keilmuan tenaga pendidik, suasana kelas dibuat kondusif dan bernuansa intelektual sehingga para siswa terlecut untuk melakukan inovasi, kreatifitas, bahkan pengembangan keilmuan melalui penggalian-penggalian pengalaman yang dimiliki. Dalam beberapa penelitian terdahulu terkait pengaruh pembelajaran advokasi pada hasil belajar siswa ternyata terbukti memberikan pengaruh yang signifikan positif meski dengan tindakan pengajaran prasiklus yang cenderung rendah dibandingkan model pembelajaran lain (Haryanto \& Suhartono, 2019). Hal ini disebabkan peran guru pengampu pada pembelajaran advokasi secara tidak langsung mendominasi melalui sistematika pembelajaran yang sebelumnya telah dibentuk (Ortiz \& Fránquiz, 2017).

\section{Pengembangan Pembelajaran Advokasi}

Sejauh ini model pembelajaran advokasi selalu diwujudkan melalui sistematika perdebatan sistematis di antara siswa dengan argumentasi yang membangun, sehingga advokasi seringkali terabaikan dalam proses pembelajaran di lapangan karena tidak semua mata pelajaran dapat dibawa pada ranah perdebatan. Namun jika menilik pada asal kemunculan pendekatan advokasi yang terinspirasi oleh psikologi belajar Gestalt (Woldt, 2009) yang dilandasi oleh pemikiran demokratisasi, maka pendekatan advokasi adalah salah satu bentuk aktualisasi demokratis di dalam kelas. Di mana siapapun di dalam kelas memiliki hak yang sama untuk belajar dan saling bertukar keilmuan. Murid dikondisikan dalam iklim pembelajaran yang penuh kebebasan dan tanggung jawab sehingga pertanyaan dan jawaban yang beragam menjadi hal lumrah dalam pembelajaran tersebut (Tandililing, 2013).

Selain itu, menilik term advokasi yang diambil dari disiplin ilmu hukum semakin menegaskan bawa karakteristik advokasi adalah upaya untuk memperoleh komitmen yang dilakukan secara persuasif menggunakan informasi yang akurat guna mengubah kebijakan atau mempengaruhi pemikiran masyarakat (Hilmawan, 2020). Tidak diketahui secara pasti kapan awal mulanya model advokasi dimaknai sebagai pembelajaran dengan model perdebatan, karena sejatinya jika model advokasi dikembalikan kepada hakikatnya maka akan ditemukan sifat advokatif pada model pembelajaran lain yang menumbuhkembangkan iklim demokratis bagi para guru dan siswa seperti model Forum Group Discussion (FGD), yang dikenal sebagai model pembelajaran diskusi yang bertujuan untung merangsang siswa memikirkan gagasan baru dan memiliki keberanian mengungkapkan ide gagasannya dengan tetap mendengarkan siswa lain dan mengadu gagasan masing-masing dengan penuh tanggung jawab (Hidayani, 2016).

Mungkin yang menjadi ciri khas dari penerapan debat sebagai perwujudan model advokatif pada penelitian-penelitian sebelumnya adalah di mana setiap topik pembahasan selalu dipandang dari 
sisi afirmasi dan oposisi (Athanases \& Martin, 2006), namun hal tersebut wajar karena model advokasi didekati melalui perdebatan dan akan menjadi berbeda jika model advokasi didekati dengan cara lain. Bahkan dapat dikatakan model pembelajaran konvensional pun mengandung unsur advokatif ketika terjadi tanya jawab antara guru dan murid, meski mungkin unsur advokatif pada model pembelajaran konvensional sifatnya lebih rendah karena iklim model konvensional yang berbasis pada teacher centered (Iswari, 2017).

Menyemai hal tersebut, maka model advokasi tidak lagi hanya dibatasi pada mata pelajaran dan materi-materi tertentu, karena advokasi dapat diaplikasikan dengan metode pengajaran yang variatif. Semisal model advokasi pada mata pelajaran matematika yang sejauh ini hanya dapat diterapkan pada materi-materi berbasis open ended (soal terbuka) yang memiliki multi jawaban (Ibrahim et al., 2021). Materi matematika multi jawaban bermakna suatu permasalahan matematika yang memiliki metode penyelesaian lebih dari satu dan seluruhnya dinilai benar. Open-Ended menjanjikan banyak kesempatan bagi siswa untuk menginvestigasi berbagai strategi dan cara yang diyakininya untuk kemudian mengelaborasi suatu permasalahan (Septiani \& Zanthy, 2019). Kini matematika dengan soal jawaban tunggal atau close ended pun tetap dapat diterapkan model advokasi dengan cara proses tanya jawab yang memberikan kesempatan luas bagi siswa untuk membangun strateginya masingmasing sebelum akhirnya guru memberikan penjelasan dan masih banyak lagi cara untuk mengaktualisasikan model advokasi.

Aktivitas diskusi dan tanya jawab atara murid dengan murid atau murid dengan guru tanpa harus disertai perdebatan sengit dan hasil akhir yang multi interpretatif juga merupakan pengembangan interpretasi dari pembelajaran advokasi di abad 21. Bahwa advokasi adalah lintas dimensi pembelajaran, ketika siswa diberikan ruang kesempatan untuk menunjukkan kemampuan dan pendapatnya meski dengan cara yang unik sekalipun pada saat itu terjadi proses advokasi dalam ranah pembelajaran. Sebaliknya, ketika siswa sebagai hilir telah proaktif maka guru harus berperan sebagai muara akhir dari validasi atau konfirmasi keilmuan di dalam kelas.

Berbicara peran guru dalam model advokasi ternyata menyajikan fakta menarik bahwa model advokasi sejatinya model pendidikan dua arah yakni guru dan murid. Artinya tidak hanya murid yang menjadi objek pendidikan di tengah pembelajaran namun juga guru. Sejauh ini, penelitian pembelajaran advokasi sama halnya dengan model-model pembelajaran lain yang tidak membahas suatu metode pembelajaran dari perspektif tenaga pendidik. Study centered tidak bermakna objektivikasi siswa. Upaya peningkatan tidak hanya berpusat pada hasil belajar siswa melainkan juga kompetensi yang dimiliki guru untuk mengimbangi model pembelajaran yang tengah digunakan. 
Bagaimana kemudian suatu model pembelajaran dapat memberikan pengaruh pada perkembangan tenaga pendidik menjadi layak untuk didiskusikan secara mendalam.

Di tengah proses pembelajaran advokasi di kelas, guru juga dituntut untuk mampu menjadi pemimpin yang baik (Bradley-Levine, 2018). Tentu tidak semua guru memiliki bekal yang cukup dalam memimpin hingga akhirnya dengan berjalannya waktu mengajar yang semakin banyak, seorang guru memiliki kemampuan memimpin yang baik. Model advokasi mendukung kebertumbuhan leadership bagi guru mata pelajaran, bagaimana kemudian guru mampu mempengaruhi siswa melalui proses perdebatan dan diskusi kritis selama pembelajaran dan sampai akhirnya menemukan inti jawaban. Selain itu, pendekatan advokasi mengajarkan pada guru untuk menerima beragam pemikiran dari siswa yang mungkin sebelumnya tidak terpikirkan olehnya (Waterston, 2009). Hal tersebut berkembang dari tahun ke tahun, pemikiran siswa masa kini mungkin akan berbeda dengan siswa di masa lalu dan guru harus mampu untuk mengakomodasi dan mengimbangi hal tersebut. Sehingga model advokasi ini adalah model pembelajaran bagi guru dan siswa.

Konsepsi fleksibilitas model advokasi di atas berangkat dari pemaknaan advokasi secara makro sehingga seluruh fungsi advokasi dapat berdampak pada peran-peran intinya seperti guru dan murid. Guru tidak lagi sebagai sumber keilmuan yang terus mentransmisikan keilmuannya tanpa adanya upgrade diri dan muridpun diposisikan sebagai objek pendidikan yang memiliki sisi multi dimensi. Fleksibilitas advokasi tidak hanya akan berdampak pada hasil belajar siswa secara kognitif namun pada penelitian-penelitian selanjutnya akan menumbuhkan dampak model advokasi pada kemampuan siswa di ranah afeksi maupun psikomotorik.

\section{KESIMPULAN}

Berbasis pada penelitian-penelitian terdahulu, dapat diketahui bahwa sejauh ini penelitianpenelitian bertema pembelajaran advokasi baru dilakukan pada lingkup yang terbatas seperti penerapan model advokasi pada pembelajaran-pembelajaran non eksak yang open-ended seperti fikih dan qur'an hadis dan juga pada pembelajaran eksak yang berbasis persoalan open-ended pada mata pelajaran matematika. Selain itu, model pengajaran advokasi masih diterapkan secara mikro yakni hanya diwujudkan melalui bentuk aktivitas perdebatan di antara siswa. Fungsi pembelajaran advokasipun masih ditilik dari sudut pandang peserta didik/siswa saja tanpa memperhatikan peranan lain seperti guru yang turut serta dalam proses tersebut. Sebagaimana dilematis model pembelajaran lain pada umumnya, advokasi baru dikaitkan secara resiprositas pada hasil belajar siswa yang sifatnya kognitif dan belum menyentuh ranah intelegensi yang lain. 
Pengembangan model pembelajaran advokasi dapat dilakukan melalui (1) aktualisasi model advokasi secara makro pada ragam metode pembelajaran yang tidak hanya terfokus pada kegiatan debat melainkan pada metode-metode pengajaran lain dengan tetap menerapkan karakteristik khusus advokasi berupa demokratis dan kritis, (2) berdasarkan keluasan penerapan model advokasi pada metode pengajaran sebelumnya maka model advokasi tidak hanya dibatasi pada topik-topik eksak ataupun non eksak, open-ended ataupun close-ended. Sebagai contoh pembelajaran fisika closeended dengan menerapkan nilai-nilai demokratis dan kritis pada siswa, atau juga pembelajaran akidah yang sifatnya rigit, (3) model advokasi merupakan proses pembelajaran dua arah, yakni guru kepada murid dan murid kepada guru sehingga keduanya sama sama diuntungkan dan saling bertukar keilmuan.

\section{DAFTAR PUSTAKA}

Abdurrahmansyah, A., \& Abdulhak, I. (2012). URGENSI PENGEMBANGAN MODEL PEMBELAJARAN UNTUK MENINGKATKAN KEMAMPUAN PEADAGOGICAL CONTENT KNOWLEDGE MAHASISWA CALON GURU AGAMA PADA FAKULTAS TARBIYAH DI PERGURUAN TINGGI AGAMA ISLAM. Ta'dib: Jurnal Pendidikan Islam, $17(01), 1-14$.

Abstrak. (n.d.). IJTIHAD DAN MUJTAHID.

Afandi, A., Junanto, T., \& Afriani, R. (2016). Implementasi digital-age literacy dalam pendidikan abad 21 di Indonesia. Prosiding SNPS (Seminar Nasional Pendidikan Sains), 3, 113-120.

Afryansih, N. (2017). Hubungan Motivasi Belajar dengan Hasil Belajar Siswa Geografi SMAN 5 Padang. Jurnal Spasial: Penelitian, Terapan Ilmu Geografi, Dan Pendidikan Geografi, 3(1).

Alexander, F., Manuain, L. M. M., Silla, W. Y., \& Dami, Z. A. (2020). Implementation of Advocacy Learning Model as A Predictor of Student's Learning Outcomes. 1st International Conference on Information Technology and Education (ICITE 2020), 149-155.

Anggrayni, Y. (2011). FAKTOR-FAKTOR YANG MEMPENGARUHI MOTIVASI BELAJAR SISWA DALAM MENGIKUTI PELAJARAN PENGAWETAN DI SMK NEGERI 1 PANDAK, BANTUL, D.I. YOGYAKARTA (Studi Kasus SMK Negeri 1 Pandak Kelas X Teknologi Hasil Pertanian 1). UNIVERSITAS NEGRI YOGYAKARTA. 
Arif, S. (2019). Higher Order Thinking Skills (HOTS) Analysis on Teachers's Questions in the Final Examination of Bahasa dan Sastra Indonesia at Senior High School 7 Medan. Budapest International Research and Critics in Linguistics and Education (BirLE) Journal, 2(4), 172178.

Athanases, S. Z., \& Martin, K. J. (2006). Learning to advocate for educational equity in a teacher credential program. Teaching and Teacher Education, 22(6), 627-646.

Barricelli, B. R., Cassano, F., Fogli, D., \& Piccinno, A. (2019). End-user development, end-user programming and end-user software engineering: A systematic mapping study. Journal of Systems and Software, 149, 101-137.

Bradley-Levine, J. (2018). Advocacy as a Practice of Critical Teacher Leadership. International Journal of Teacher Leadership, 9(1), 47-62.

Chiruguru, S. B. (2020). The essential skills of 21 st century classroom (4Cs).

Cooper, H. M. (1988). Organizing knowledge syntheses: A taxonomy of literature reviews. Knowledge in Society, 1(1), 104-126.

Dahlan, J. A. (2004). MENIGKATKAN KEMAMPUAN PENALARAN DAN PEMAHAMAN MATEMATIKA SISWA SEKOLAH LANJUTAN TINGKAT PERTAMA MELALUI PENDEKATAN PEMBELAJARAN OPEN-ENDED. Universitas Pendidikan Indonesia.

Dananjaya, U. (2010). Media pembelajaran aktif. Nuansa cendekia.

Darmawan, K. Z. (2006). Komunikasi instruksional dalam proses pembelajaran mahasiswa. Mediator: Jurnal Komunikasi, 7(1), 125-138.

ET, O. D. E. C. (n.d.). 21st Century Learning: Research, Innovation and Policy.

Firmannisa, D., \& Imaniyati, N. (n.d.). Keterampilan Mengajar Guru dan Fasilitas Belajar Sebagai Determinan Terhadap Prestasi Belajar Siswa Kelas X Administrasi Perkantoran. Jurnal Pendidikan Manajemen Perkantoran (JPManper), 5(1), 45-55.

Fox, I., \& Wiens, J. (2019). Advocacy Learning: Learning through Competition and ClassConditional Representations. ArXiv Preprint ArXiv:1908.02723.

Hamalik, O. (1991). Pendekatan baru strategi belajar-mengajar berdasarkan CBSA. Penerbit Sinar Baru Bandung.

Hamalik, O. (2008). Proses Belajar Mengajar, Jakarta: PT. Bumi Aksara. 
Hamid, E. A. (2019). TANGGAPAN SISWA TERHADAP MODEL PENGAJARAN ADVOKASI HUBUNGANNYA DENGAN MOTIVASI BELAJAR MEREKA PADA MATA PELAJARAN FIQIH. Al-Mujaddid: Jurnal Ilmu-Ilmu Agama, 1(2), 70-88.

HARTINI, S. R. I. T. (n.d.). Kemampuan Koneksi Matematis Siswa Melalui Pendekatan Advokasi dengan Penyajian Masalah Open-Ended pada Pembelajaran Matematika di SMP Swasta AlWasliyah TP 2017/2018.

Haryanto, H., \& Suhartono, S. (2019). Upaya Peningkatan Hasil Belajar Mata Pelajaran Al-Qur'an Hadits Melalui Penerapan Metode Advokasi. Al-I'tibar: Jurnal Pendidikan Islam, 6(1), 34-44.

Hidayani, S. (2016). Penerapan Model Pembelajaran Focus Group Discussion Dalam Meningkatkan Kemampuan Berpikir Kreatif Dan Hasil Belajar PAI Siswa SD Negeri 05 Kepahiang. Annizom, $1(3)$.

Hilmawan, T. (2020). STRATEGI DAN ADVOKASI PONDOK PESANTREN DALAM MENYELESAIKAN MASALAH KONFLIK SOSIAL (Studi Analisis Pondok Pesantren AlIttihad Jabung Lampung Timur). Al-Syakhsiyyah: Journal of Law \& Family Studies, 2(1), 150 167.

HIMPUNAN FATWA MAJELIS ULAMA INDONESIA. (n.d.).

Hirschman, K., \& Wood, B. (2018). 21st century learners: Changing conceptions of knowledge, learning and the child. New Zealand Annual Review of Education, 23, 20-35.

Ibrahim, I, Sujadi, I., Maarif, S., \& Widodo, S. A. (2021). Increasing Mathematical Critical Thinking Skills Using Advocacy Learning with Mathematical Problem Solving. Jurnal Didaktik Matematika, 8(1), 1-14.

Ibrahim, Ibrahim. (2020). DESAIN PENYAJIAN MATERI PERSAMAAN GARIS LURUS DI SMP BERORIENTASI KETERAMPILAN BERPIKIR TINGKAT TINGGI. Media Pendidikan Matematika, 8(2), 1-15.

Ibrahim, Ibrahim, \& Widodo, S. A. (2020). ADVOCACY APPROACH WITH OPEN-ENDED PROBLEMS TO MATHEMATICAL CREATIVE THINKING ABILITY. Infinity Journal, 9(1), 93-102.

Ifa, M. (2013). Penerapan model pembelajaran kooperatif tipe jigsaw untuk meningkatkan hasil belajar siswa kelas X SMK Negeri 3 Boyolangu pada standar kompetensi menerapkan keselamatan dan kesehatan kerja (k3). Jurnal Pendidikan Teknik Elektro, 2(2). 
Iswari, A. P. (2017). Perbandingan Hasil Belajar Antara Model Pembelajaran Konvensional Dengan Model Pembelajaran Kooperatif Tipe Team Accelerated Instruction (TAI) pada Mata Pelajaran Mekanika Teknik Kelas X TGB DI SMK Negeri 2 Surakarta.

Lilik, W. (2021). PENERAPAN MODEL PEMBELAJARAN ADVOKASI UNTUK MENINGKATKAN HASIL BELAJAR FIQIH SISWA KELAS VIII DI MTS RAUDLATUL ULUM SUNGKAI SELATAN LAMPUNG UTARA. UNIVERSITAS ISLAM NEGERI RADEN INTAN LAMPUNG.

Lisnawati, L. (2020). Penggunaan Pendekatan Belajar Advokasi Berpusat pada Siswa dalam Meningkatkan Prestasi Belajar Siswa pada Mata Pelajaran IPS Kelas VIII di MTS. Nurussalam Tetebatu kecamatan Sikur TA. 2019/2020. Jurnal Al-Mutaaliyah: Jurnal Pendidikan Guru Madrasah Ibtidaiyah, 5(1), 91-104.

Marfuah. (2017). Meningkatkan Keterampilan Komunikasi Peserta Didik melalui Model Pembelajaran Kooperatif Tipe Jigsaw. Jurnal Pendidikan Ilmu Sosial., 26(2), 48-160.

Mukharrom, M. T. (2004). Teologi Advokasi. Al-Mawarid Journal of Islamic Law, 12(11), 26021.

Mustolih, M. (2020). Upaya Peningkatan Hasil Belajar Siswa Mata Pelajaran Fiqih Materi Pembelajaran Haji dan Umrah Melalui Penerapan Metode Advokasi. Jurnal Profesi Keguruan, 6(1), 100-109.

Nurwahidah, N., \& Muttaqin, Z. (2018). Peran Guru Pkn Dalam Model Pengajaran Advokasi Untuk Meningkatkan Pemahaman Isu-Isu Sosial Pada Siswa. CIVICUS: Pendidikan-PenelitianPengabdian Pendidikan Pancasila Dan Kewarganegaraan, 6(2), 88-97.

Oktiani, I. (2017). Kreativitas Guru dalam Meningkatkan Motivasi Belajar Peserta Didik. Jurnal Kependidikan, 5(2), 216-232.

Ortiz, A. A., \& Fránquiz, M. E. (2017). Co-editors' introduction: The central role of advocacy in ensuring excellence in education for English learners. Taylor \& Francis.

Palittin, I. D., Wolo, W., \& Purwanty, R. (2019). Hubungan motivasi belajar dengan hasil belajar siswa. Magistra: Jurnal Keguruan Dan Ilmu Pendidikan, 6(2), 101-109.

RAHMAWATI, R. (n.d.). FAKTOR-FAKTOR YANG MEMPENGARUHI MOTIVASI BELAJAR SISWA KELAS X SMA NEGERI 1 PIYUNGAN PADA MATA PELAJARAN EKONOMI TAHUN AJARAN.

Redhana, I. W. (2019). Mengembangkan keterampilan abad ke-21 dalam pembelajaran kimia. Jurnal Inovasi Pendidikan Kimia, 13(1). 
Romdloni, R. (2018). Peningkatan Efektivitas Pembelajaran Pendidikan Agama Islam (PAI) melalui Manajemen Kelas. Evaluasi, 1(2), 151-166.

Septiani, U., \& Zanthy, L. S. (2019). Pembelajaran Matematika Melalui Pendekatan Open-Ended Terhadap Pemahaman Matematik Siswa MTs. Jurnal Cendekia: Jurnal Pendidikan Matematika, 3(1), 58-63.

Setiawan, I., \& Nyoman, G. A. (2008). Penerapan pengajaran kontekstual berbasis masalah untuk meningkatkan hasil belajar biologi siswa kelas x2 sma laboratorium singaraja. Jurnal Penelitian Dan Pengembangan Pendidikan, 2(1), 42-59.

Silberman, M. L. (2020). Active learning 101 cara belajar siswa aktif.

Sinaga, S. E. (2013). Perbedaan kemampuan berpikir kritis dan kreatif siswa SMP dalam matematika dengan pembelajaran konvensional melalui pendekatan advokasi dengan penyajian masalah open-ended. UNIMED.

Sjukur, S. B. (2012). Pengaruh blended learning terhadap motivasi belajar dan hasil belajar siswa di tingkat SMK. Jurnal Pendidikan Vokasi, 2(3).

Suharto, E. (2007). Pekerjaan Sosial di Dunia Industri: Memperkuat Tanggungjawab Sosial Perusahaan (Corporate Social Responsibility). Bandung: Refika Aditama.

Suminah, S., Gunawan, I., \& Murdiyah, S. (2018). Peningkatan Hasil Belajar dan Motivasi Belajar Siswa melalui Pendekatan Behavior Modification. Ilmu Pendidikan: Jurnal Kajian Teori Dan Praktik Kependidikan, 3(2), 221-230.

Sunbanu, H. F., Mawardi, M., \& Wardani, K. W. (2019). Peningkatan Keterampilan Kolaborasi Siswa Menggunakan Model Pembelajaran Kooperatif Two Stay Two Stray Di Sekolah Dasar. Jurnal Basicedu, 3(4), 2037-2041.

Syahputra, E. (2018). Pembelajaran abad 21 dan penerapannya di Indonesia. Prosiding Seminar Nasional SINASTEKMAPAN, 1(1), 1277-1283.

Tabroni, T. (2013). Upaya Menyiapkan Pendidikan Yang Berkualitas. Al-Fikrah: Jurnal Kependidikan Islam IAIN Sulthan Thaha Saifuddin, 6, 56613.

Tafsir, A. (2019). Filsafat Pendidikan Islami: Integrasi Jasmani (9th ed.). PT. Remaja Rosdakarya.

Tandililing, E. (2013). Pengembangan kemampuan koneksi matematissiswa melalui pendekatan advokasi dengan penyajian masalah open-ended pada pembelajaran matematika. Prosiding Seminar Nasional Matematika Dan Pendidikan Matematika FMIPA UNY, 9. 
Triandini, E., Jayanatha, S., Indrawan, A., Putra, G. W., \& Iswara, B. (2019). Metode Systematic Literature Review untuk Identifikasi Platform dan Metode Pengembangan Sistem Informasi di Indonesia. Indonesian Journal of Information Systems, 1(2), 63-77.

Ulfah, K. R., Santoso, A., \& Utaya, S. (2016). Hubungan motivasi dengan hasil belajar ips. Jurnal Pendidikan: Teori, Penelitian, Dan Pengembangan, 1(8), 1607-1611.

Waterston, T. (2009). Teaching and learning about advocacy. Archives of Disease in ChildhoodEducation and Practice, 94(1), 24-28.

Woldt, A. L. (2009). Gestalt pedagogy-Creativity in teaching. Gestalt Review, 13(2), 135-148.

Yanuarti, H., \& Rosmayanti, D. (2019). THE RELATIONSHIP BETWEEN STUDENTS'MOTIVATION AND THEIR LEARNING ACHIEVEMENT. PROJECT (Professional Journal of English Education), 1(6), 783-788.

Zulyadi, T. (2014). Advokasi Sosial. Jurnal Al-Bayan: Media Kajian Dan Pengembangan Ilmu Dakwah, 20(2). 